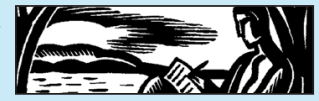

\title{
'The Cruelty Towards Others Like Ourselves... is Difficult to Imagine Here as You Turn to Swim Your Twentieth Length' \\ Swimming and Dreaming of Elsewhere with John Berger
}

\author{
Jo Croft
}

John Moores University, Liverpool

\section{ABSTRACT}

Swimming, like reading, is an immersive activity: words wash away, and words arise. Engaging with writings by critics who are also swimmers, principally John Berger and Maurice Merleau-Ponty, this article explores their writings about swimming in relation to how being in water can 'conjure stories from the water', and open up particular kinds of reflection and reverie. The fluidity of water spaces creates an imaginary that enables intellectually sensuous dreaming, while the ebb and flow of movements and identifications establish a poetics of swimming as a form of life writing.

Keywords: water, swimming, Berger, Merleau-Ponty, Bachelard

\section{‘... THE WATER HOLDING UP BOTH ME AND WHATEVER STORY I'M PUZZLING OVER' (BERGER 2011)}

In 'On Vigilance' (2016), when John Berger writes about swimming up and down one of his favourite municipal pools in Paris, he summons up an almost utopian vision of the 'egalitarian anonymity' afforded by such 
communal spaces. As he dives under water, he describes 'the sensation of having entered another time-frame' (Berger 2016:67). And at first it seems that breaching the surface of the pool allows him to escape from 'the pain of living in the present world' (Berger 2003). After all, 'the cruelty towards others like ourselves... is difficult to imagine here as you turn to swim your twentieth length' (Berger 2016:68).

Yet, as he 'swims on (his) back' and 'looks up at the sky through the framed glass roof', Berger also meditates upon traumatic events happening elsewhere. 'Held by the water', he recalls 'stories told by minuscule ice crystals in the silence of the blue' (71): he charts the patterns of a cirrus cloud's 'undulations', and follows the drifts of these 'material reveries' (Bachelard: 1942: 155-156) to Gaza, where 20 Palestinians have been 'blown to pieces in their homes' the previous day. He thinks of '35 illegal immigrants... suffocating in a shipping container that had crossed the North Sea to dock in London' (Berger 2016:71).

Whereas for Oliver Sacks (another celebrated swimmer), swimming offers 'a sort of joy, a sense of well-being so extreme that it becomes at times a sort of ecstasy' (Sacks 1997: n.p.), for Berger, the rhythms of swimming do not simply offer 'pure' escape or relaxation. Something more complex, more ambivalent seems to be at stake. Immersed in this shared container of chlorinated water, Berger spins, or confabulates stories as he moves. But what such stories carry with them, it seems, is that selfsame cruelty which at first he had found so 'difficult to imagine' (Berger 2016:68).

As swimmers, what both Sacks and Berger do share is a capacity to conjure stories from the water. In Sacks's case, apparently, most of his book A Leg to Stand On 'was written (with) the paragraphs forming themselves during long swims at Lake Jeff and being discharged, every half hour or so, drippingly, on to paper' (Sacks 1997: n.p.). It is as if swimming and writing for Sacks are more or less the same thing-his movements across the lake immediately anticipate the movement of words across paper. Swimming strokes become pen strokes. Lake water turns into ink.

But for Berger there is a different kind of textual transcription happening as he swims. Despite his insistence that in the pool 'Everywhere the horizontal [...] dominates' (Berger 2011:122), his stories seem to form in a more vertical dream-like space, where strokes, and words, float in a 'preverbal' (6) state of suspended animation, where gaps in consciousness are 'held' by the water. For all its 'odd horizontal equality' (122), Berger's municipal pool is shaped by confabulations, which span the space above and below the pool's surface. His texts are drafted in the clouds moving above him as he floats on his back, and in the pinnate leaves of a maple tree that he glimpses just beyond the pool's glass walls. 


\section{'THAT STRING OF POOLS, THAT \\ QUASI-SUBTERRANEAN STREAM’ (CHEEVER 1964)}

Berger's 2016 description of a pool contains the palimpsest of an earlier representation of swimming: in his 2004 essay 'Marc Trivier: My Beautiful' he writes about a pool in Paris which is probably the same 'favourite' pool that features in 'On Vigilance'. He also mentions another public bath-'a pool in Eastbourne', where his father taught him to swim in 1931. Just as he follows a drift of thought in 'On Vigilance', here again Berger moves across different spaces and moments, following in the wake of a chain of associations initially prompted by Trivier's photograph of a single leg of an Alberto Giacometti sculpture. Such a narrative almost seems to take on the shimmering, refracting structure of a 'glitter path' (Gooley 2016:138): patterns of light on contained water carry Berger from a photo to a pool, and then to another pool, before drifting back once more to Giacometti's figures. The quality of light in Trivier's photograph reminds Berger of 'the light in an indoor swimming pool' (Berger 2004:191), which in turn takes him back to the pool in Eastbourne, with its red and white lifebelt bearing the inscription Eastbourne Town Council.

Almost as an aside, Berger tells us that 'I think I learnt to read easily, and to swim in the same year-1931' (192). Perhaps that's why he remembers the words on the lifebelt. In any case, he represents himself as becoming a swimmer and a reader at more or less the same time, and he seems to have taken both to books, and to water, with ease. Yet this apparent breeziness about mastering words and water is undercut by a more diffident strain in his qualified phrase 'I think I learned' (my italics). There is a slight hesitation here which hints at a hazy sense of his own history, one which emulates the sensation of swimming without goggles... that 'slight haze' which he associates both with the stinging blur of chlorine as you leave the pool, and with the 'opacity of thought' itself (196).

\section{SWIMMING AND READING 'WITHOUT GOGGLES'...}

The swimming pool, it seems, invites its own paradoxical forms of literacy. As we enter the water, we are assailed by signs-'The Hairdryer will be shut off 5 minutes before closing-time. Bathing Caps Obligatory. Council Decree.' (122) — and we learn to read (or perhaps to ignore) their 'distinctive bureaucratic syntax and vocabulary' (122). Like Ned Merrill in John Cheever's story, 'The Swimmer', we are 'confronted' with a regimented discourse which attempts to order and punctuate our actions: 'ALL SWIMMERS MUST TAKE A SHOWER BEFORE USING 


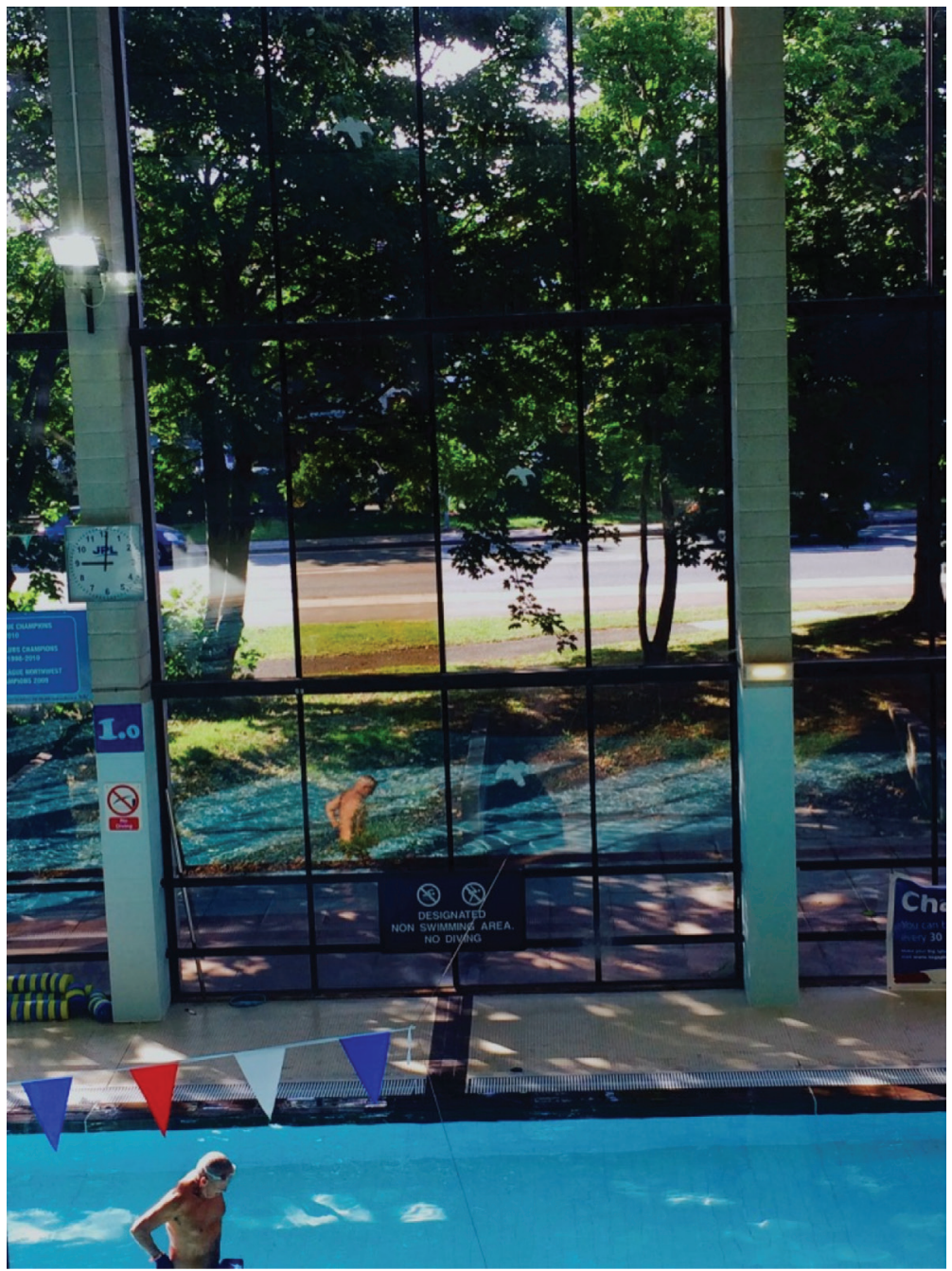

Figure 1. Swimmer leaving West Kirby Swimming Pool.

THE POOL. ALL SWIMMERS MUST USE THE FOOTBATH. ALL SWIMMERS MUST WEAR THEIR IDENTIFICATION DISKS' (Cheever 1964:732). My own local pool has a sign telling us to 'swim clockwise'.

But, according to Berger, it is in the pool that we also learn, or re-learn, the syntax of 'wordlessness' - that 'wordless language which we have been reading since early childhood but which I cannot name' (Berger 
2016:69). Such a language finds its way to Berger as he swims on his side. He 'watch(es) a tree.' He dreams of his next drawing. It will be a sketch of a silver maple. It will move in and out, span scales: from the detail of a single leaf to an image of the whole tree. It will be 'a kind of text' (69) made not with words, but with strokes in the water.

Berger's description of pool swimmers who seek out 'the odd and deep pleasure of carrying out something private and alone in company' (Berger 2004:195) is reminiscent of a readerly sensorium, perhaps because both activities are associated with immersive states. Or-as Gillian Best puts it-'Swimming and reading have a lot in common: both are solitary pursuits, escapes into different worlds and different kinds of freedom' (Best 2017: n.p.). But the relationship between reader and swimmer is not simply analogical for Berger. Sometimes, the act of 'reading' in the pool becomes far less figurative, and more like Bachelard's 'material reverie'-'a type of syntax, a continual linking up and gentle movement of images that free a reverie bound to objects' (Bachelard 1942:13).

\section{‘THROUGH THE WATER'S THICKNESS’ (MERLEAU-PONTY)}

In much of his writing about swimming pools, Berger seems to be grasping for ways to connect different registers of perception. Sometimes the water itself is a text. Sometimes it is a lens. Either way, the water opens up 'an interface, a shared skin between the physical and the metaphysical' (194). In 'Marc Trivier: My Beautiful', Berger describes 'A middleaged woman holding on to the pool's edge, looking concentratedly at the water, which reaches her collarbones, as if it's a book she's reading' (Berger 2004:196). Here, a porous exchange seems to take place between water, body and thought. The woman 'reads' herself, both inside and outside, through the water's 'shared skin'.

There are remarkable parallels between scenes like this and MerleauPonty's description in 'Eye and Mind' of looking 'through the water's thickness' at 'the tiled bottom of the pool' (Merleau-Ponty 1964:142). Like Berger, Merleau-Ponty pictures the water-borne gaze as reflexive and embodied, giving its 'flesh' to what he sees through its distorting lens of ripples and reflections. Thus when Merleau-Ponty writes about water as 'the aqueous power, the syrupy and shimmering element', he also summons up its 'inner animation' (142). Like Berger, he pictures a realm of perception which is 'not contained there' (in the pool), but which allows for identifications to take place both 'in depth' and reciprocally. Just as Berger looks up at the clouds through the pool's glass roof and sees that 'the curls of the white cirrus are observing a man afloat on 


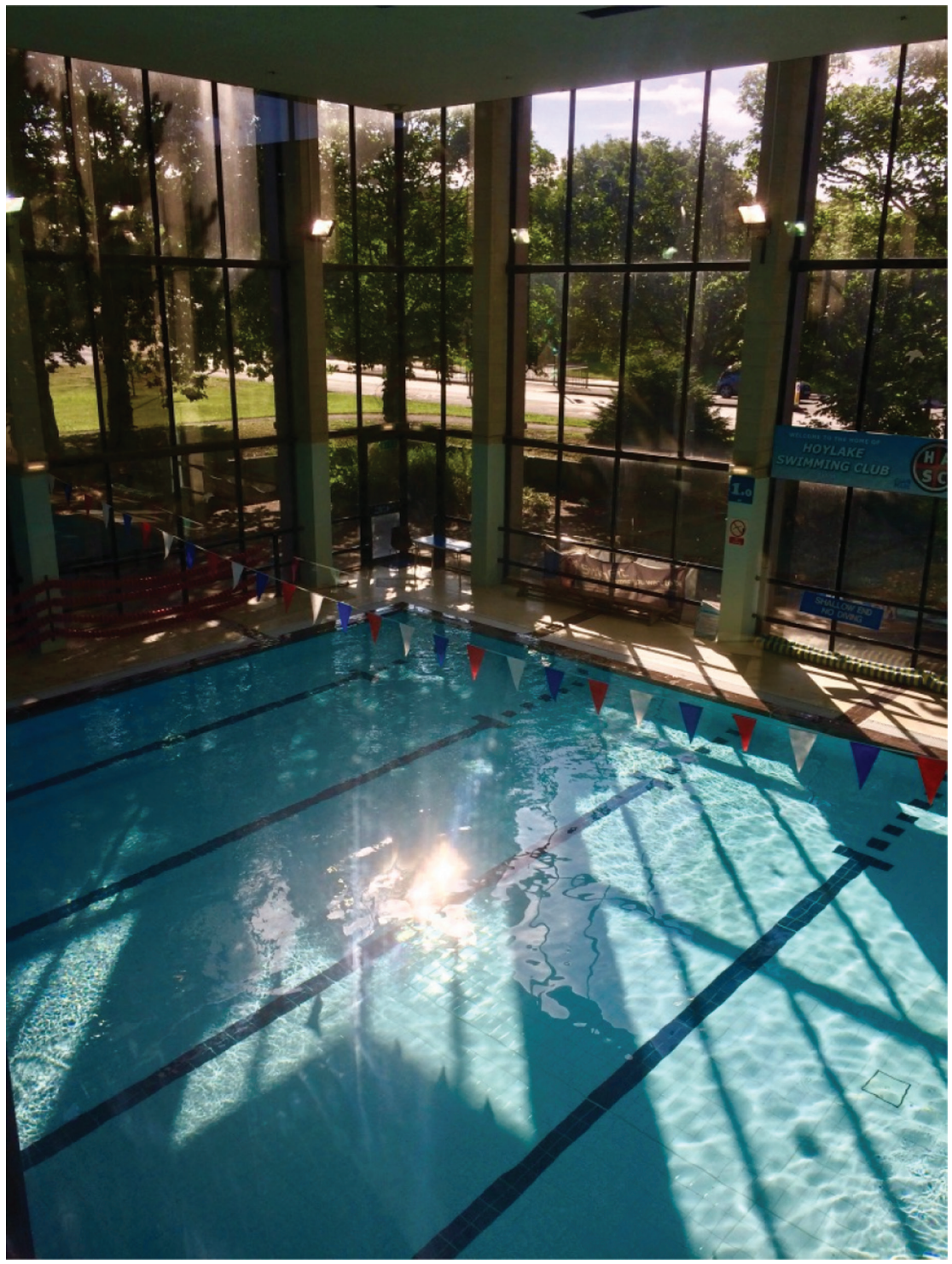

Figure 2. Empty West Kirby Pool.

his back' (Berger 2016:71), so Merleau-Ponty 'lifts his eyes' beyond the pool 'toward the screen of cypresses where the web of reflections plays', and 'recognize(s) that the water visits it as well, or at least sends out to it its active, living essence' (Merleau-Ponty 1964:142). 


\section{'WE BOTH TROD WATER AND SHE SMILED'} (BERGER 2011)

Berger tells more stories about swimming in Bento's Sketchbook (2011a). The one he tells most vividly is about his relationship with another swimmer, a Cambodian artist. Their friendship begins as they 'lifted (their) heads and nodded at one another' while they are both swimming lengths, 'cross(ing) one another in opposite directions' (Berger 2011a: 125). Across the lanes of the pool, a gesture-a 'signal'-momentarily disrupts the intricate choreography of the swimmers' routines.

The pulse of the water-its rituals and rhythms of 'immersion and extraction' (124) - then carries them beyond the water as they meet outside, 'beneath the weeping willows' (126). Again, Berger moves between the rhythms of a public pool, and his thoughts about 'the pain of others' (Sontag 2003). As he listens to the swimmer's traumatic history-her escape from Cambodia in the mid-1970s, her life of exile, and her struggles with polyarthritis-he finds it 'impossible to separate the pain to which her body was apparently heir from the pain of her country's history during the last half century' (127). And, as if to emphasize this connection between the swimmer's bodily pain and her country's suffering, the word 'Polyarthritis' itself takes on the status of a place, its repetition in Berger's narrative marking its territory (c.f. Deleuze and Guattari: 1987): 'She answered immediately, as if naming a place: Polyarthritis' (127), and a few paragraphs later '... she had said the word Polyarthritis, pronouncing it as if it were a place' (128).

There is an ebb and flow of identifications, of 'immersion and extraction' throughout Berger's narrative of this encounter: not only between bodies across the lanes of the pool, but between bodies of water-from the municipal pool to the rivers of Cambodia, 'a land with a unique, osmotic relationship with fresh water' (127). Berger even seems to suggest a mirroring between the lap swimmer's 'up and down' movements in the pool, and the waters of Cambodia's Tonle Sap. As the Tonle Sap lake overflows and swells each summer, so the water of its river 'turns round to run in the opposite direction, its downstream becoming upstream' (128).

Water-borne movements also flow through Berger's text in the form of brushstrokes. The Cambodian artist's frog-like swimming style reminds Berger of the watercolors of Qi Baishe, whose frogs looked like they were wearing bathing caps. This may be one of the reasons that he gives her 'his precious Sho Japanese paint brush.' In return, she gives him a painting of a bird, left 'on the bench by the diving boards' (129). And later, when Berger looks more closely, he reads her drawing of a bird as an 
expression of 'homelessness.' He realizes that the blue tit is copied from the Larousse encyclopedia, and for all its delicacy, it is stitched into the wrong landscape. Not quite a fish out of water, it is a bird perched on the wrong kind of branch. Only the bamboo's 'liquid' brushstrokes gesture back to the country that the artist has left behind, and remind us that 'the Khmer word for homeland is Teuk-Dey, which means Water-Land' (127).

'NO FUTURE, NO WORDS, AND NOWHERE TO GO' (BERGER 2011)

It is the summer of 2011 (the same year that Bento's Sketchbook is published) and Berger is watching TV coverage of the riots taking place in Croydon. [The 2011 riots started in Tottenham, following the police shooting of a local man, Mark Duggan, on 4 August 2011. Rioting spread across London and beyond.]

This time, as he traces another constellation of temporal and spatial connections, it is a lake, not a swimming pool, which becomes the site of Berger's confabulations. In his short essay, 'The Time We Live', Berger's thoughts jump from one place to another-from the mediatized images of the Croydon riots to 'a miniature and modest seaside resort... [where] those who gather there are on vacation. They have left their everyday lives behind somewhere. Maybe a few kilometers away, maybe hundreds. They have emptied themselves' (Berger 2011b: n.p.).

Berger struggles to identify with the images he sees on screen of 'the kids [...] rioting because they had no future, no words and no where to go.' Yet there is something in these 'pictures' that he does recognize, something which seems to offer a conduit to this urgent present happening in another place. This is because this same place, with its 'desperately violent present', coincides with Berger's own past: he was once a child in Croydon too, and he remembers visiting a Croydon shop with his mother in the 1930s, perhaps one of the same shops he now sees going up in flames on TV.

Unable to 'share his reactions' with his 'long since dead' mother, Berger reaches for the name of a shop ('Kennards. Kennards!') to restore her presence. In grasping for this 'password'-a shard of memory carried in a name-Berger also seeks to span the gap that seems to have opened up between his own life and those of another generation (of kids in Croydon). And as he grasps for connections between the past and present of one location, Berger also transports his readers from one geographical space to another elsewhere, away from the UK riots to a deep lakeprobably Lake Geneva-where some very different kinds of gathering are happening: the lake waters mingle with the river Rhône, the Arctic Char 
gather to breed, and people gather together 'on vacation'... to play, and perhaps to swim.

In a series of sensual snapshots, Berger describes how the people on holiday are full of 'expectancy' and 'promises.' Such promises are 'wordless and physical'. Unanchored from linguistic and visual registers of articulation, they are perceived more porously, through a supposedly 'lower' sensorium of touch, taste, sound: 'The taste of chocolate. The width of her hips. The splashing of water. The length of the daughter's drenched hair' (Berger 2011b: n.p.). Berger reminds us that 'The etymological root of the word vacation is the Latin vacare, to be empty, to be free', and he pictures this 'elsewhere' by the lake as a place which is both empty and full. It is a place of 'mostly reclining freedoms' where 'messages in the pulse' can be heard, touched, or tasted, where there is a loosening of the divisions between past, present, and future. Or put another way, this is a place where 'being empty' makes daydreaming possible.

\section{'WE ARE ALL OBJECTS OF SOMEONE ELSE'S DREAM' (CHAMBERS 2016)}

When he writes about swimming in 2016, Berger tells us only that his favorite municipal pool is in Paris, but when he writes about swimming in 2004, he is a bit more specific about the pool's location, noting how it is close to Fresnes' 'notorious Maison D’Arrêt' (Berger 2004:195). Berger doesn't expand upon the reasons for the prison's notoriety. ${ }^{1}$ Yet, simply by mentioning that these two very different kinds of 'containing' spaces share a neighborhood in the Parisian suburbs, he again touches upon the contiguity of 'limitless cruelty to others like ourselves.'

While the voices of Fresnes prison never explicitly permeate the walls of the pool, Berger's narrative seems to hint that these spaces are connected: perhaps through a shared municipal infrastructure of streets and sewers; and perhaps through a shared constellation of dreams. After all, in his 'Open Letter to Raymond Barre, the Mayor of Lyon' (Berger 2001: 185), Berger specifically nominates the prison as a dream space, where 'endless small dreams' circulate - 'dreams of the sea', 'of privacy', and 'of private time'; dreams 'of women', 'open doors' and 'the furious dream of putting an end to everything' (189). And he asks the following rhetorical question: 'What kind of building ... houses the most dreams? School? Theatre? Cinema? Library? Intercontinental Hotel? Discotheque? Mightn't it be a prison?' (Berger 2001:189).

For Berger, there is more than one way to dream, and he reminds us that 'dreams include nightmares and insomniac terrors' (Berger 2001:188). It is this latter version of dreaming which seems to leak through the walls 
of the prison, and to radiate from 'the kids in Croydon', living 'isolated but together, in the desperately violent present' (Berger 2011b: n.p.). Of course, there are kids in Berger's favorite Parisian pool too, and he guesses that, like the kids in Croydon, they are there because they don't have the luxury of 'emptying' themselves on vacation. They are-'kids whose families couldn't afford to leave Paris' (Berger 2011a:128). And yet, unlike the kids in Croydon, these kids who spend their summer 'jumping in feet first, holding their noses' seem, at least for the time being, to be drawn into the wake of another narrative, 'objects of someone else's dream' (Chambers 2017: 125). Just for a while, they are conduits to that elusive reverie of egalitarian leisure which Berger sometimes glimpses as he dives in the pool - a dream once optimistically anticipated in the 'relaxed simple outlines of Fernand Léger's Plongeurs paintings, but which now is 'further away than ever' (Berger 2011a: 123). Their splashing and shouting mingle with the child's laughing 'somewhere in the distance' which Berger imagines as he hears the laughter of the Cambodian artist. Laughter is a current flowing against the 'measured impersonal committee voice' of the pool's 'bureaucratic syntax' (123).

\section{'EXILED FROM THIS VILLAGE, EXCLUDED FROM REAL LIFE' (MERLEAU-PONTY 1945)}

I arrive in a village for the holidays, happy to leave behind my work and my ordinary surroundings. I settle into the village. It becomes the center of my life. The low level of water in the river, or the corn or walnut harvest, are events for me. But if a friend comes to see me and brings news of Paris, or if the radio and newspapers inform me that there are threats of war, then I feel exiled from this village, excluded from real life, and imprisoned far away from everything. Our body and perceptions always solicit us to take the landscape they offer as the center of the world. But this landscape is not necessarily the landscape of our life. I can 'be elsewhere' while remaining here, and if I am kept from what I love, I feel far from the center of real life. (Merleau-Ponty 1945: 299)

When Merleau-Ponty writes about 'lived space' in The Phenomenology of Perception (1945), he draws directly on his own experience of being 'elsewhere.' At first, when he describes leaving Paris 'for the holidays' to spend time in the countryside, his account reads like a celebration of bucolic rhythms-'I settle into the village. It becomes the center of my life. The low level of water in the river, or the corn or walnut harvest, are events for me' (299). Apparently, though, it is not long before this 'happy' state of 
being away from his everyday existence (being 'empty' in Berger's terms) is overtaken by ambivalence.

For Merleau-Ponty, the circadian rhythms of village life only ever seem to constitute a temporarily deflection of trauma. The Phenomenology of Perception was first published in 1945, and contains few direct references to the fact that Merleau-Ponty has been writing in the shadow of the Nazi Occupation of France. Nevertheless, there are moments when the text becomes more explicitly riven with ethical and political conflict. And even though the countryside's flows and repetitions seem to become Merleau-Ponty's own pulse for a while ('The center of my life'), this embodied relation to another, more 'natural' landscape is impossible to sustain. The landscape of 'real life', with its 'news of Paris' and 'threats of war', soon encroaches again on this 'elsewhere', and he feels 'excluded', 'imprisoned' in this other version of 'waking life' (229).

\section{'BUT THIS LANDSCAPE IS NOT NECESSARILY THE LANDSCAPE OF OUR LIFE’ (MERLEAU-PONTY 1945)}

It is the summer of 2017, and I am 'elsewhere', swimming in a tributary of the Ardèche. For more than three decades I have returned, year after year, to this same stretch of the Chassezac River. Each day, when I swim, I re-trace a single meander of this 'clear, green water' (Bachelard 1942:8). And in these briefly bracketed-off stretches of time, away from the most entrenched patterns of work and home, the river becomes 'the pulsation of [my] existence, its systole and diastole' (Merleau-Ponty 1945:298).

As I swim first upstream and then down, against the current, and then back with it again, I mark my course with the same staging posts each time: this overhanging branch, the rock where you can dive, the shallow stretch where I can feel the bed of the river bumping my knees. Moving through the water, I find myself becoming intensely aware of the different smells that cross my path—traces of marshy, slightly sulphurous algae from the murky little pools to my left. This is slow water, but then I take a few more strokes upstream and water flows faster against me, with cleaner, earthier smells-geosmin, carp and warm granite; invasive whiffs of suntan cream and sweat, then back to tree pollen, grass, leafy muddiness. A delicate but intoxicating smell drifts in thin pulses across from the undergrowth. I can never quite trace it to its source. Maybe it's coming from the trees.

Sounds flow in and out too: grating canoe bottoms, and the odd shout; a splash half-registered, in Auden's 'quite leisurely way', as a boy's 'white 
legs disappear into the green water' (Auden 1938:179). Something about the damp mixture of plastic and sun and water and plants takes me right back to being underwater in a paddling pool and feeling like I'm in an ocean. This is the same smell-sun blue and warm through the plastic sides, and the water laced with grass cuttings.

When I am swimming, or floating, in this river-scape, my thoughts often seem to drift 'towards something that has gone, or is awaited, (is) hidden elsewhere in another place' (Berger 2005:141). It is as if my refrain-like movements, my immersion in this 'truly transitory element' (Bachelard 1942:6), provoke a heightened sense of subjective permeability and exchange. Divisions between different times, different places, seem less certain. I am 'a being in flux' (Bachelard 1942:6).

The river gnaws at the limestone. This is the same pulse of water which made the Chauvet Cave, about thirty kilometers downstream from here.

In his essay, 'Le Pont d'Arc', Berger tells us that 'the waters of the Ardèche have made many caves in the plateau of the Bas Vivarais' (Berger 2005:129). The Chauvet Cave contains paintings that are more than 30,000 years old and, since its discovery in 1994, Berger is one of the only people to have been given access to the site. Berger first writes about the Chauvet Cave in 2001, in The Shape of a Pocket, but it is in his 2005 essay that he gives a first-hand account of visiting the cave. He begins with the 'sound of water, flowing over polished stones', and 'the river, full of swirls, fast-flowing, metallic-looking in the sunlight', and tells us that 'it tugs like a dog at the imagination, asking you to come for a walk' (Berger 2005:129). In other words, his narrative follows the echoes and refractions proffered by the water. The Ardèche is 'like a dog'. As readers, we are like dogs too, pulled by the water's sensory trajectories. Drawn into its ambit of sound and light and smell.

Berger goes on to describe both the space of the cave, and the paintings themselves using a language of water. The caves 'all have in common that they look like forms created by flowing water' (134) and he reads the Cro-Magnon paintings as if they too are the brushstrokes of an ancient river: 'Cro-Magnon painting did not respect borders. It flows where it has to, deposits, overlaps, submerges images already there, and it continually changes the scale of what it carries' (140).

Sensing the presence of Cro-Magnon people in the extraordinary artwork and darkness of the cave, Berger ends his essay with a rather haunted, enigmatic address to the hunters and hunted of Chauvet-'who are where? Here, come from elsewhere?' (Berger 2005:142). According to Berger, the nomad cave painters have a 'notion of past and future (which) is subservient to the experience of elsewhere' (Berger's italics). 


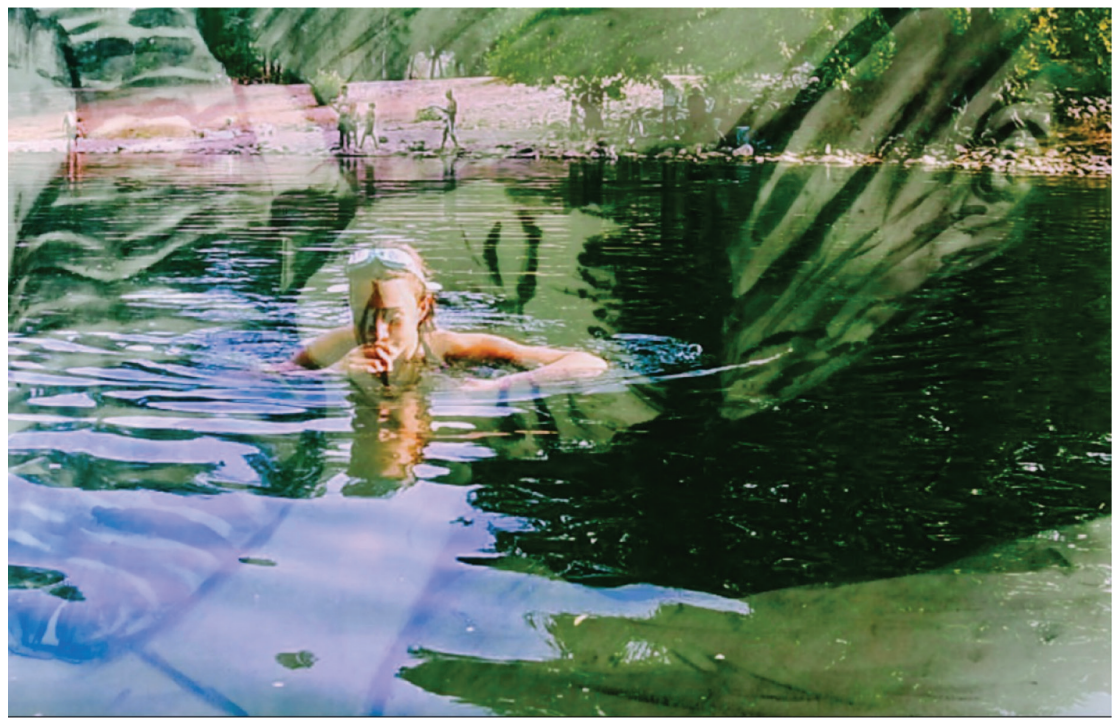

Figure 3. Rosa in the Chassezac.

In other words, the idea of elsewhere summoned up by the ghosts of Chauvet seems to re-configure temporality itself as 'another place' (141). Whereas he argues that 'the culture of globalisation' has 'no elsewhere or otherwise' (214), Berger seems to picture the imaginative space inhabited by Cro-Magnons as contingent upon an elsewhere 'experience (d)' as an intertwining, a confluence of matter and memory. Time and place flow together... they deposit, submerge, and overlap.

\section{WE TALK ABOUT DROWNING...}

Summer 2016. My sister-in-law's mother has just drowned in the Aegean Sea. Nobody seems to know how or why. She had swum from the same beach in Poros for more than 60 years. It was her favorite place, her favorite stretch of sea.

I am swimming in the Chassezac with my daughter. She has brought her books down to the water's edge, but for now her pile of densely scrawled notes, full of bright slashes of color, and impenetrable clusters of numbers, are abandoned on the rock. As we swim downstream, we talk about osmosis. After a year of studying medicine Rosa has learned that there are at least two ways to drown. Apparently, our bodies respond differently 
to seawater and freshwater. Their different chemistries invite different kinds of death: when we drown in the sea, we suffocate. Salt draws out water from the surrounding cells in our lungs, creating a film of water lining the alveoli which is too thick for gases to diffuse across, so we are starved of oxygen. But when we drown in a river, the water is more diluted than our own cytoplasm: our cells take in water by osmosis, they swell and burst, releasing a flood of sodium and potassium ions, interfering with the electrical conductivity of our heart, so we die by cardiac arrhythmiaour heart stops. Either way, as Bachelard reminds us, 'Water always flows, always falls, always ends in horizontal death' (Bachelard 1942:6).

\section{NOT SWIMMING BUT DROWNING... (OR THE STRANGE STORY OF CORKER'S DROWNING DOG)}

There is a drowning in Berger's 1964 novel Corker's Freedom. While giving a talk to the local parish social club, Corker invites the audience to look at his photo of 'always moving' water, and he points out that 'You can learn a lot from the stream' because what is 'so nice about streams is that you can stand by the side of them. You can let them go past you' (Berger 1964:203). He then starts to describe how he has watched a dog drown in a 'stream near Horn.' This story is riven with interruptions and digressions, flowing back on itself, and sometimes getting caught up in stagnant asides. Corker's own narrative voice is dispersed across different registers-between what he 'knows', what he 'says' and what he 'thinks.' There are moments when we hear the inner voices of his audience too. 'Oh to be dead and to be the element 'I think I ought to be', thinks Miss Brand' (205).

At first what seems to be at stake here is a sentimental scene: a little white $\operatorname{dog}$ follows Corker and his friends when they are out walking. The dog runs along on the path, jumping in and out of the stream's fast flowing water, 'snapping at the white foam', and trying to 'stop[ping] the current' (203-204). Here the dog seems to mirror a human ambivalence to the water, at once drawn to, and repelled by the stream's flow. At this point, Corker's audience might well anticipate that the story will move on to some sort of epiphanic moment which reveals the potential for intimate connections between animals and humans. But the narrative fails to sustain this vision of inter-species affection, because after a while one of Corker's companions becomes 'very angry.' The dog has made him wet. He begins to throw stones at the dog: although 'None of them hit him, he went on throwing stones at it and stones into the stream as well' (204). And so, through a complex play of shifting identifications, the dog becomes less human, and more water. Less 'he' and more 'it'. 
The scene shifts again. Corker follows the stream on his own, and is in turn followed by the white dog, who continues to jump in and out of the water. Eventually the dog drops out of sight, and Corker waits, 'dreaming' and watching the water rush over the weir. Despite, or perhaps because, the drowning dog also seems to be dreaming, 'its nose pointing right up to the sky, almost vertical [...] a funny fixed stare too', its fate almost seems to merge with Corker's state of reverie.

As this trauma unfolds, we-both slide-show audience and readers of the novel-are transfixed by the image of the white dog disappearing over the edge of the weir, 'something white in the water [...] trying to swim against the stream' (Berger 1964:206). At this point in the narrative, it is interesting that the dog becomes 'he' again rather than 'it', and with this shift in pronoun, another shift takes place. Now the drowning dog is a suicidal dog, refusing rescue. Corker offers the dog a stick but 'He just wouldn't take it. He didn't even try to bite on it. He just went on staring up with that fixed stare at the sky' (207).

We are told that Corker 'has forgotten his audience and doesn't know where the story is going to end' (207). Perhaps, though the problem is precisely the opposite: our own 'horror of drowning', like Corker's, is carrying us along toward the weir too, and the story we hear is not about connecting with the non-human. Instead, it speaks only of our human fears of non-connection, of failing to register suffering: 'I didn't hear his splash at the bottom. Not a trace of him [...] All I could hear was the rush and something turning in the water' (207-208).

\section{THINK ABOUT ICARUS}

There are no clouds at all this afternoon, but, just for a moment, the trace of thunder hangs in the sky. There's a thud a bit like a blunt firework. Then nothing again. The sky is the brightest blue, nothing else. I am hanging, floating in the green. After a while, I hear sirens coming from the other side of the river, winding and shrieking up the mountain. And then fading again.

In the evening a neighbor tells us that a car has driven off the side of the mountain. I think back to the afternoon, and my memory shifts, finds new shapes. Now I picture myself floating in the river, but this time I catch a glimpse of a ball of flame falling, bump bump bumping down the side of the mountain. My eyes feel tired with the sun. The sky is frayed. I think about Icarus, and how 'nobody heard the splash'. I am floating in the river. I am bulky but also miraculously weightless. I am oblivious like that 'delicate ship'. 


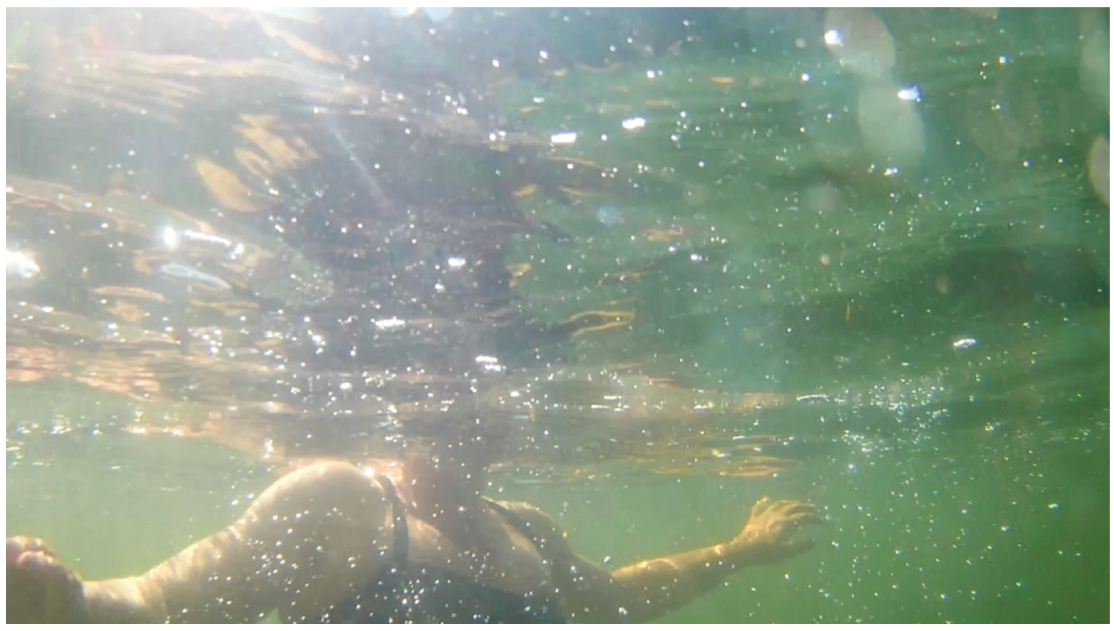

Figure 4. In the Chassezac.

\section{CONCLUSION}

In Gaston Bachelard's Water and Dreams (1942), there are only a couple of cursory references to swimming pools. In fact, Bachelard more or less dismisses the swimming pool's potential as a space for dreaming, arguing not only that it has a 'ridiculous name' ('la piscine' in the original French version), but that it cannot 'provide the ideal of solitude, so necessary for the psychology of a cosmic challenge' (Bachelard 1942:168). While Berger repeatedly celebrates the swimming pool as a site of both social connection and psychic elaboration, for Bachelard it seems only to connote constriction and contrivance: water without flow, 'piscine' without fish.

So why do Berger and Bachelard portray swimming pools so differently? One possible answer is that Bachelard dreams by the water, but Berger swims in the pool. When Bachelard writes that he "cannot sit beside a stream without falling into a profound reverie, without picturing my youthful happiness' (Bachelard 1942: 8) he suggests a form of identification between subject and water which is intimate and yet bounded. For Berger, on the other hand, a swimming pool allows for a 'swirl' of possible identifications, both temporally and spatially- 'movements and contours that may at any moment offer a sense of extended participation' (Bell 2016: 216-217). 
From a pool to Trivier, to Giacometti, to another pool (or maybe the same pool) and then to a lake, and a prison, and a cave, and a river. A drowning dog and a car falling out of the sky. Then, finally, back to the river. This is the glitter path that forms in the wake of Berger's un-goggled swimmer's gaze. For Berger, it is as if the pool is a place where the boundaries between ourselves and others become a little more fuzzy, and where - if only temporarily - we are less firmly anchored by the fixed co-ordinates of rational perception - 'thinking (that) only clarifies' (Berger: 2004, 196). 'The slight haze' afforded by the water allows us to view the world differently, and perhaps brings us closer to a 'seamless world of wordlessness.' Like Calvino, who 'define(s) the opaque as a declaration that the world I am describing does have a reverse side' (Calvino: 1990, 147) Berger, the swimmer, offers us an invitation to apprehend the world differently: to enter the pool, to look at the world 'without goggles', and to immerse ourselves in 'the opacity of thought'.

\section{REFERENCES}

All images by the author.

\section{WORKS CITED}

Atkins, William. 2017. 'Key Strokes: Writer as Swimmer.' https://www.gladstoneslibrary.org/ news/volume/key-strokes-writer-as-swimmer-by-will-atkins. Date accessed: 27 February 2017.

Auden, W.H. 1938. 'Musée des Beaux Arts.' In: Edward Mendelson (ed.), W.H. Auden: Collected Poems. London: Faber and Faber, 1994 [1976].

Bachelard, Gaston. Air and Dreams: An Essay on the Imagination of Movement. Dallas: Dallas Institute Publications, 1988 [1943].

Bachelard, Gaston. Water and Dreams: An Essay on the Imagination of Matter. Dallas: Dallas Institute Publications, 1983 [1942].

Bell, Vikki. 'Stars.' In: Yasmin Gunaratnam and Amarjit Chandan (eds.), A Jar of Wild Flowers: Essays in Celebration of John Berger. London: Zed Books, 2016.

Berger, John. Corker's Freedom. London: Verso, 2010 [1964].

Berger, John. And Our Faces, My Heart, Brief as Photos. London: Bloomsbury, 2005 [1984].

Berger, John. The Shape of a Pocket. London: Bloomsbury, 2001.

Berger, John. 'Written in the Night: The Pain of Living in the Present World.' Le Monde diplomatique. http://www.hartford-hwp.com/archives/27a/113.html. Date accessed: February 2010.

Berger, John. 'Marc Trivier: My Beautiful.' In: Understanding a Photograph. London: Penguin Books, 2013 [2004].

Berger, John. 'Between Here and Then: Marc Trivier.' In: Understanding a Photograph. London: Penguin Books, 2013 [2005].

Berger, John. Here is Where We Meet. London: Bloomsbury, 2005. 
Berger, John. Bento's Sketchbook. London: Verso, 2011a.

Berger, John. 'The Time We Live.' https://www.opendemocracy.net/ourkingdom/johnberger/time-we-live. Date accessed: 23 August 2011b.

Berger, John. Confabulations. London: Penguin, 2016.

Best, Gillian. 'Top 10 Books About Swimming.' In: Guardian, July 5, 2017. https://www.theguardian.com/books/2017/jul/05/top-10-books-about-swimming.

Calet, Henri. Les Murs de Fresnes. Paris: Éditions des Quatre vents, 1945.

Calvino, Italo. The Road to San Giovanni. Boston and New York: Mariner Books, 1993 [1990].

Chambers, Iain. 'Method.' In: Yasmin Gunaratnam and Amarjit Chandan (eds.), A Jar of Wild Flowers: Essays in Celebration of John Berger. London: Zed Books, 2016.

Cheever, John. 'The Swimmer.' In: Collected Stories and Other Writings. New York: Library of North America, 2009 [1964].

Cléro. Jean-Pierre. 'Maurice Merleau-Ponty et la guerre.' In: Revue philosophique de la France et de l'étranger 127 (2003) 315-331.

Deakin, Roger. Waterlog. London: Vintage Books, 1999.

Deleuze, Gilles and Guattari, Félix. A Thousand Plateaus. London: Bloomsbury, 2013 [1987].

Englebert, Theo. 'Dans L'Enfer de la Prison de Fresnes.' StreetPress https://www.streetpress.com/sujet/1515429429-10-requetes-cedh-prison-fresnes.

Gooley, Tristan. How to Read Water: Clues, Signs and Patterns from Puddles to the Sea. London: Sceptre, 2016.

Graham, Elspeth. 'Geraniums (red) and delphiniums (blue)': Trauma, Ethics, and Medical Communications.' Journal of Medical Humanities 38:2 (2017) 151-172.

LeFebvre, Henri. Rhythmanalysis: Space, Time and Everyday Life. Trans. by Stuart Elden and Gerald Moore. London: Bloomsbury, 2013 [1992].

Merleau-Ponty, Maurice. The Phenomenology of Perception. London: Routledge, 2014 [1945].

Merleau-Ponty, Maurice. 'Eye and Mind.' In: Galen A. Johnson and Michael B. Smith (eds.), The Merleau-Ponty Aesthetics Reader: Philosophy and Painting. 1993. Illinois: Northwestern University Press, 1964.

Sacks, Oliver. 'Water Babies.' In: New Yorker. May 261997.

Sartre, Jean-Paul. 'Paris Under Occupation.' Sartre Studies International 4:2 (1998) [1949] 1-15. First published in France libre. London, 1945.

Shapton, Leanne. Swimming Studies. London: Penguin, 2014 [2012].

Sontag, Susan. Regarding the Pain of Others. New York: Picador, 2003.

Sprawson, Charles. Haunts of the Black Masseur: The Swimmer as Hero. London: Vintage, 2013 [1992].

Ward, Miranda. 2017. 'Swimming in a contained space: Understanding the experience of indoor lap swimmers.' In: Health E Place 46 (2017) 315-321.

\section{ABOUT THE AUTHOR}

Jo Croft was a Senior Lecturer in English Literature at Liverpool John Moores University, specialising in psychoanalysis, spatial theory, and eco-criticism. She completed her PhD on 'Adolescence and Writing: Locating the Borderline' at Sussex University; and published Our House: The Representation of Domestic Space in Modern Culture in 2006 (edited, with Gerry Smyth). Croft's subsequent research centred on material mobilities (especially hoarding, beachcombing, gleaning and swimming); these themes are also explored in two earlier articles, in Humanities 7 (2018) and Life Writing 17 (2020). She developed her research using 
cabinet-based installations, and audio-visual formats. Her short films about swimming have been screened at conferences, and as part of an exhibition about swimming ('Nofio') at Aberystwyth Art Centre. Jo Croft died in January 2021.

\section{NOTE}

1 Fresnes Prison was known as a place of torture and mass execution during the German Occupation (Calet 1945) and has also been the site of recent protests about inhuman living conditions (Englebert 2018). 